\title{
Faktor Pembentuk Kepuasan Kerja Tenaga Kesehatan di Rumah Sakit
}

\section{Determinant Factor of Health Worker Job Satisfaction at Hospital}

\author{
Nanditya IF ${ }^{1}$, Mohammad Mansur ${ }^{2}$, Samsul Huda ${ }^{3}$ \\ ${ }^{1}$ Rumah Sakit Prasetya Husada Malang \\ ${ }^{2}$ Program Studi Magister Manajemen Rumah Sakit Fakultas Kedokteran Universitas Brawijaya Malang \\ ${ }^{3}$ Rumah Sakit Wava Husada Kepanjen
}

\begin{abstract}
ABSTRAK
Tingkat turnover tenaga kesehatan yang tinggi dapat berpengaruh terhadap kualitas pelayanan Rumah Sakit. Salah satu faktor yang mempengaruhi turnover tenaga kesehatan adalah kepuasan kerja yang juga dipengaruhi oleh banyak faktor. Penelitian ini bertujuan untuk mengetahui faktor yang membentuk kepuasan kerja tenaga kesehatan yang menurunkan angka turnover dan kinerja RS. Metode penelitian adalah deskriptif analitik dengan responden 84 tenaga kesehatan yag terdiri dari perawat, bidan, farmasi, analis laboratorium, radiografer, ahli gizi, perekam medis, dan fisioterapis. Sampel diambil dengan menggunakan teknik purposive sampling. Data dikumpulkan melalui kuesioner dan diukur dengan skala Likert 5 tingkat. Data dianalisis dengan analisa faktor. Hasil penelitian menunjukkan bahwa terbentuk faktor intrinsik dan ektrinsik yang mempengaruhi kepuasan kerja. Faktor intrinsik yang terbentuk adalah penghargaan. Faktor ektrinsik yang terbentuk adalah kebijakan RS, gaji dan kompensasi, lingkungan kerja dan hubungan antara atasan dengan bawahan. Terdapat masalah komunikasi yang mempengaruhi persepsi kepuasan kerja oleh tenaga kesehatan di RSX.
\end{abstract}

Kata Kunci: Faktor ektrinsik, faktor intrinsik, kepuasan kerja, tenaga kesehatan

\begin{abstract}
High health worker's turnover rate can affect hospitalquality service. One factor that influence turnover's rate is job satisfaction which is also influenced by many factors. This study aims to determine the factors that form job satisfaction of health workers which lower the number of employee turnover rate and increase hospital's performace. The research method is descriptive analytic with 84 health workers as respondents consisting nurses, midwives, pharmacists, laboratory analysts, radiographers, dietitians, medical recorders and physiotherapists. Samples were taken by using purposive sampling technique. Data were collected through questionnaires and measured with a 5-level Likert scale. The data were analyzed using factor analysis. The result shows that job satisfaction was formed by byintrinsic and extrinsic factors. Intrinsic factor formed is award system. Extrinsic factors formed are hospital policy, salary and compensation, working enviroment and the relationship between supervisor and employees. There is a communication problem that affects the perception of job satisfaction among health workers in X hospital.
\end{abstract}

Keywords: Extrinsicfactors, health workers, intrinsicfactors, job satisfaction

Jurnal Kedokteran Brawijaya, Vol. 28, Suplemen No. 1, 2014: Nanditya IF. Rumah Sakit Prasetya Husada Malang, Jl. Raya Ngijo No. 25 Karangploso Tel. (0341) 460558Email:nandityaif@gmail.com 


\section{PENDAHULUAN}

Pencapaian kinerja Rumah Sakit dapat diukur dengan menggunakan balanced score card melalui pendekatan empat perspektif: keuangan, pelanggan, proses bisnis internal serta pembelajaran dan pertumbuhan (1). Melalui pendekatan perspektif pembelajaran dan pertumbuhan di Rumah Sakit $X$ (RS X) terdapat permasalahan di bidang Sumber Daya Manusia (SDM) khususnya tenaga kesehatan yang terdiri dari tenaga medis keperawatan (perawat dan bidan) serta tenaga medis penunjang (farmasi, analis laborat, radiografer, gizi, perekam medis dan fisioterapis). Berdasarkan data, terdapat peningkatan turn over tenaga kesehatan di RS X pada tahun 2012 dibandingkan tahun 2011 sebesar 2\%. Fenomena ini berbanding terbalik dengan turn over tenaga non kesehatan yang cenderung menurun di tahun 2012 dibandingkan tahun 2011 sebesar 2\%. Selain itu, proporsi turn over karyawan di RS $\mathrm{X}$ didominasi oleh tenaga kesehatan yaitu sebesar $60 \%$.

Tingkat turn over yang tinggi menimbulkan ketidakpastian kinerja organisasi, dan peningkatan biaya SDM (2). Peningkatan turn over pada tenaga kesehatan di RS $X$ merupakan potensi yang dapat menurunkan kinerja pelayanan rumah sakit. Hal ini disebabkan karena tenaga kesehatan merupakan ujung tombak dari pelayanan pasien di rumah sakit.

Salah satu faktor yang mempengaruhi turn over karyawan adalah kepuasan kerja. Apabila kepuasan kerja karyawan terhadap pekerjaannya rendah, maka karyawan tersebut berpotensi untuk keluar dari pekerjaannya (2). Untuk mengetahui tingkat kepuasan kerja, perlu dilakukan pengukuran kepuasan kerja. Manajemen SDM RS X belum melakukan pengukuran tingkat kepuasan kerja karyawan sehingga masih sulit memprediksi potensi turnover karyawannya.

Salah satu upaya untuk menurunkan angka turn over adalah dengan cara meningkatkan kepuasan kerja yang dapat dicapai dengan memperhatikan faktor-faktor yang membentuknya. Menurut teori Herzberg, kepuasan kerja disebabkan oleh faktor intrinsik dan ekstrinsik. Faktor intrinsik merupakan faktor yang berhubungan dengan pekerjaan itu sendiri, yaitu prestasi, kompetensi, pengakuan, tanggung jawab, dan pengembangan untuk maju. Faktor ekstrinsik adalah faktor yang berada di sekitar pelaksanaan pekerjaan yaitu gaji, rasa aman, lingkungan kerja, rekan kerja serta hubungan atasan dan bawahan (3).

Dengan mengetahui faktor-faktor yang berpengaruh pada kepuasan kerja tenaga kesehatan di RS X diharapkan dapat memberikan solusi untuk meningkatkan kepuasan kerja tenaga kesehatan dan secara tidak langsung menurunkan angka turnover tenaga kesehatan di RS X. Hasil penelitian juga memberikan masukan untuk pembinaan tenaga kesehatan yang masih ada sehingga meningkatkan kinerja Rumah Sakit.

\section{METODE}

Penelitian ini termasuk penelitian deskriptif dengan pendekatan analisa kuantitatif. Data diperoleh dari survei kepuasan tenaga kesehatan di RS X melalui kuesioner. Pertanyaaan pada kuesioner dibuat sebagai hasil dariFocus Group Discussion (FGD). Anggota FGD terdiri dari 8 (delapan) orang yang berasal dari masing-masing satu perwakilan dari bidan, perawat, tenaga farmasi, ahli gizi, analis laboratorium, perekam medis, fisioterapis dan radiografer. Dari hasil FGD didapatkan 29 (duapuluh sembilan) pertanyaan yang mewakili faktor intrinsik dan ekstrinsik yang membentuk kepuasan kerja di RS X serta satu pertanyaan yang mewakili tingkat kepuasan kerja secara umum.

Skala pengukuran yang digunakan pada kuesioner ini adalah skala Likert. Opsi jawaban tersebut terdiri atas lima pilihan dari mulai sangat tidak setuju sampai dengan sangat setuju (2). Terdapat pertanyaan terbuka mengenai alasan responden jika memilih jawaban ragu-ragu, tidak setuju dan sangat tidak setuju.

Populasi penelitian adalah seluruh tenaga kesehatan yang bekerja di RS $X$ yang bekerja minimal satu tahun dan sudah menjalani orientasi pegawai baru sebanyak 140 orang. Teknik sampling dilakukan dengan cara cluster proportional purposive sampling. Populasi dibagi menjadi delapan kelompok tenaga kesehatan yang memiliki ciri-ciri yang sama yaitu: kelompok perawat, bidan, analis kesehatan, radiografer, asisten apoteker, ahli gizi, perekam medis dan terapis. Jumlah sampel yang diambil dari masing-masing kelompok populasi tersebut dihitung berdasarkan prosentase jumlahnya dibandingkan keseluruhan tenaga kesehatan. Berdasarkan rumus Slovin, dengan tingkat kepercayaan $11 \%$ didapatkan jumlah sampel yang diperlukan sebesar 84 orang. Variabel penelitian merupakan pernyataan yang termasuk dalam faktor intrinsik dan ekstrinsik. Variabel dari faktor intrinsik adalah: kompetensi, penghargaan, kesempatan untuk berkembang, kreatifitas, tanggung jawab dan pencapaian. Variabel dari faktor ekstrinsik adalah: kebijakan Rumah Sakit, gaji dan kompensasi, rasa aman,lingkungan pekerjaan, teman sekerja dan hubungan atasan dengan bawahan. Dari kedua variabel tersebut dikembangkan 30 pernyataan pada kuesioner. Sebelum kuesioner disebarkan dilakukan uji validitas dan realibilitas sehingga diperoleh 21 pernyataan di dalam kuesioner yang valid dan reliable.

Analisa data kuantitatif pada penelitian ini menggunakan analisis faktor dengan pendekatan eksplanatori. Analisis faktor ini digunakan untuk mengeksplorasi variabelvariabel manifes yang ada, sehingga nantinya akan terbentuk faktor-faktor yang kemudian akan dilakukan interpretasi untuk menentukan variabel-variabel laten apa yang diperoleh. Salah satu tujuan analisis faktor adalah mereduksi jumlah variabel dengan cara mirip seperti pengelompokan variabel (4). Dalam analisis faktor dilakukan langkah-langkah : uji kecukupan sampel dengan Matrix Sample Analysis (MSA),matrix korelasi, ekstraksi faktor untuk mendapatkan loading factor dan rotasi faktor (5).

\section{HASIL}

\section{Karakteristik Responden}

Karakteristik 84 responden yang mengisi kuesioner disajikan pada Tabel 1. Hasil menunjukkan bahwa hampir seluruh jumlah responden (99\%) termasuk ke dalam kelompok usia produktif atau dewasa muda (20-49 tahun).Pada kelompok usia produktif ini proporsi terbanyak adalah usia antara 26-30 tahun (44\%). Jenis kelamin responden terbanyak adalah perempuan (69\%), sedangkan sisanya adalah laki-laki (31\%). Tempat tinggal responden sebanyak $50 \%$ di daerah Kepanjen dan sisanya 
sebanyak $50 \%$ di luar Kepanjen. Status perkawinan terbanyak adalah kawin $69 \%$ dan status kepegawaian terbanyak adalah pegawai tetap (64\%).

Responden terdiri dari tenaga kesehatan keperawatan (perawat dan bidan) serta tenaga kesehatan penunjang (asisten apoteker, ahli gizi, analis laboratorium, perekam medis, fisioterapis dan radiografer). Berdasarkan pengelompokkan tersebut, maka porposi tenaga kesehatan keperawatan sebesar $69 \%$ dan tenaga kesehatan penunjang sebanyak $31 \%$.

Dari Tabel 1 diketahui bahwa responden terbanyak telah bekerja selama lebih dari 2 tahun lamanya di RS X (60\%). Tingkat pendidikan responden terbesar adalah D3 (97\%). $\mathrm{Hal}$ ini mencerminkan bahwa tingkat pendidikan tenaga kesehatan di RS X cukup tinggi. Untuk persepsi responden mengenai besar gaji mereka dibandingkan dengan UMR, sebesar $51 \%$ menyatakan sesuai UMR, $10 \%$ diatas UMR,8\% dibawah UMR dan 31\% tidak menjawab.

Tabel 1. Karakteristik responden kuesioner kepuasan kerja tenaga kesehatan RSX

\begin{tabular}{|c|c|c|c|}
\hline Karakteristik & Uraian & $\begin{array}{l}\text { Jumlah } \\
\text { (orang) }\end{array}$ & $\begin{array}{c}\text { Prosentase } \\
(\%)\end{array}$ \\
\hline \multirow[t]{5}{*}{ Umur Responden } & $<20$ tahun & 1 & 1 \\
\hline & $20-25$ tahun & 35 & 42 \\
\hline & $26-30$ tahun & 37 & 44 \\
\hline & 31- 35 tahun & 10 & 11 \\
\hline & $>35$ tahun & 1 & 1 \\
\hline \multirow[t]{2}{*}{ Jenis Kelamin } & Laki-laki & 26 & 31 \\
\hline & Perempuan & 58 & 69 \\
\hline \multirow[t]{2}{*}{ Tempat Tinggal } & Kepanjen & 42 & 50 \\
\hline & Luar Kepanjen & 42 & 50 \\
\hline \multirow[t]{2}{*}{ Status Perkawinan } & Kawin & 58 & 69 \\
\hline & Belum Kawin & 26 & 31 \\
\hline \multirow[t]{2}{*}{ Status Kepegawaian } & Tetap & 54 & 64 \\
\hline & Kontrak & 30 & 36 \\
\hline \multirow[t]{8}{*}{ Profesi } & Perawat & 53 & 63 \\
\hline & Bidan & 5 & 6 \\
\hline & Asisten Apoteker & 11 & 13 \\
\hline & Ahli Gizi & 2 & 2 \\
\hline & Perekam Medis & 4 & 5 \\
\hline & Fisioterapis & 2 & 2 \\
\hline & Analis Laborat & 6 & 8 \\
\hline & Radiografer & 2 & 1 \\
\hline \multirow[t]{4}{*}{ Jabatan } & Kepala Unit & 11 & 13 \\
\hline & Penanggung & 3 & 4 \\
\hline & Jawab shift & & \\
\hline & Pelaksana/staff & 70 & 83 \\
\hline \multirow[t]{2}{*}{ Lama Bekerja di RSX } & $1-2$ tahun & 38 & 40 \\
\hline & $>2$ tahun & 46 & 60 \\
\hline \multirow[t]{3}{*}{ Tingkat Pendidikan } & SMA/SMK & 2 & 2 \\
\hline & D3 & 81 & 97 \\
\hline & $\mathrm{S} 1$ & 1 & 1 \\
\hline \multirow[t]{4}{*}{ Besar Gaji } & Dibawah UMR & 8 & 10 \\
\hline & Sesuai UMR & 43 & 51 \\
\hline & Diatas UMR & 7 & 8 \\
\hline & Tidak Menjawab & 26 & 31 \\
\hline
\end{tabular}

Keterangan: Jumlah seluruh sampel $(n)=84$ orang Sumber: Data Kuesioner Diolah (2013)

\section{Gambaran Umum Kepuasan Kerja Tenaga Kesehatan}

Secara umum sebagian besar tingkat kepuasan responden adalah cukup. Pada faktor intrinsik hasil menunjukkan bahwa responden tidak puas pada kesesuaian sistem reward dengan kebijakan serta kesempatan untuk jenjang karier. Pada faktor ekstrinsik, responden tidak merasa puas pada informasi mengenai waktu kenaikan gaji. Hanya teman sekerja yang merupakan salah satu faktor ekstrinsik yang dinilai memuaskan tenaga kesehatan.

Deskripsi variabel penelitian dapat dijelaskan berdasarkan mean masing-masing variabel. Interpretasi puas jika nilainya diatas 4, cukup puas apabila nilainya diantara 3-4 , dan tidak puas jika dibawah 3.

\section{Tabel 2. Gambaran kepuasan kerja tenaga kesehatan}

\begin{tabular}{|c|c|c|c|c|}
\hline Faktor & Sub Faktor & Variabel Pernyataan & Mean & Intepretasi \\
\hline \multirow[t]{5}{*}{ Intrinsik } & Penghargaan & $\begin{array}{l}\text { Kesesuaian sistem reward } \\
\text { dengan pedoman }\end{array}$ & 2,89 & $\begin{array}{l}\text { Tidak } \\
\text { puas }\end{array}$ \\
\hline & & $\begin{array}{l}\text { Besarn gaji pada karyawan } \\
\text { yang telah lama bekerja } \\
\text { dibandingkan yang baru } \\
\text { bekerja }\end{array}$ & 3,13 & Biasa \\
\hline & $\begin{array}{l}\text { Kesempatan } \\
\text { untuk }\end{array}$ & $\begin{array}{l}\text { Kesempatan untuk jenjang } \\
\text { karier }\end{array}$ & 1,99 & $\begin{array}{l}\text { Tidak } \\
\text { puas }\end{array}$ \\
\hline & berkembang & $\begin{array}{l}\text { Kesempatan yang sama } \\
\text { untuk mengikuti seminar dan } \\
\text { pelatihan }\end{array}$ & $n^{3,65}$ & Biasa \\
\hline & $\begin{array}{l}\text { Tanggung } \\
\text { jawab }\end{array}$ & $\begin{array}{l}\text { Melakukan wewenang sesuai } \\
\text { tanggung jawabnya }\end{array}$ & ai 3,15 & Biasa \\
\hline \multirow[t]{11}{*}{ Ekstristik } & $\begin{array}{l}\text { Kebijakan } \\
\text { Rumah Sakit }\end{array}$ & $\begin{array}{l}\text { Kesesuaian antara hak dan } \\
\text { kewajiban dalam perjanjian } \\
\text { kerja dengan prakteknya }\end{array}$ & 3,88 & Biasa \\
\hline & & $\begin{array}{l}\text { Kebijakan punishmen yang } \\
\text { dilakukan }\end{array}$ & 3,46 & Biasa \\
\hline & & $\begin{array}{l}\text { Kesesuaian HRD dalam } \\
\text { menanggapi komplain yang } \\
\text { berkaitan dengan gaji }\end{array}$ & 3,17 & Biasa \\
\hline & & Pola ketenagaan di unit & 3,76 & Biasa \\
\hline & & $\begin{array}{l}\text { Jumlah cuti dan libur sesuai } \\
\text { ketentuan yang berlaku }\end{array}$ & 3,56 & Biasa \\
\hline & & $\begin{array}{l}\text { Kesesuaian informasi } \\
\text { mengenai kebijakan waktu } \\
\text { kenaikan gaji dengan } \\
\text { prakteknya }\end{array}$ & 2,38 & $\begin{array}{l}\text { Tidak } \\
\text { puas }\end{array}$ \\
\hline & $\begin{array}{l}\text { Gaji dan } \\
\text { Kompen-sasi }\end{array}$ & $\begin{array}{l}\text { Jumlah gaji yang didapatkan } \\
\text { berdasarkan perjanjian kerja }\end{array}$ & 3,79 & Biasa \\
\hline & & Kompensasi lemburan & 3,69 & Biasa \\
\hline & $\begin{array}{l}\text { Teman } \\
\text { sekerja }\end{array}$ & $\begin{array}{l}\text { Kemudahan teman sekerja } \\
\text { untuk diajak bekerjasama }\end{array}$ & 4,21 & Puas \\
\hline & $\begin{array}{l}\text { Hubungan } \\
\text { atasan } \\
\text { dengan } \\
\text { bawahan }\end{array}$ & $\begin{array}{l}\text { Kemudahan komunikasi } \\
\text { dengan manajeman/atasan } \\
\text { jika ada komplain yang } \\
\text { bekaitan dengan pekerjaan }\end{array}$ & 3,45 & Biasa \\
\hline & & $\begin{array}{l}\text { Tanggapan dan kepastian } \\
\text { solusi dari } \\
\text { manajemen/atasan } \\
\text { mengenai permasalahan yg } \\
\text { berkaitan dengan pekerjaan }\end{array}$ & 3,23 & Biasa \\
\hline
\end{tabular}


Tabel 2. Gambaran kepuasan kerja tenaga kesehatan (Lanjutan)

\begin{tabular}{lllll}
\hline Faktor & Sub Faktor & Pernyataan & Mean & Intepretasi \\
\hline & $\begin{array}{l}\text { Lingkungan } \\
\text { kerja }\end{array}$ & $\begin{array}{l}\text { Sarana dan Prasarana } \\
\text { lingkungan kerja }\end{array}$ & 3,51 & Cukup \\
$\begin{array}{l}\text { Kepuasan } \\
\text { secara } \\
\text { umum }\end{array}$ & $\begin{array}{l}\text { Tingkat kepuasan bekerja di } \\
\text { RSX }\end{array}$ & 3,56 & Cukup \\
& & & & \\
\hline
\end{tabular}

Sumber: Data penelitian yang diolah, 2013

\section{Faktor Pembentuk Kepuasan}

Analisis data dilakukan dengan uji analisis faktor. Variabelvariabel yang telah teruji validitas dan realibilitasnya dilanjutkan untuk analisis faktor. Dari variabel-variabel tersebut dilakukan ekstraksi dengan metode Principal Componenet Analysis (PCA). Jumlah faktor yang telah ditetapkan sebanyak dua yaitu faktor intrinsik dan ekstrinsik. Apabila nilai PCA pada variabel lebih besar daripada nilai koefisien 0,5 berarti variabel tersebut mewakili faktor yang terbentuk. Setelah melakukan enambelas (16) kali analisis faktor didapatkan hasil yang disajikan pada Tabel 3.

Tabel 3. Komponen matriks hasil analisis faktor

\begin{tabular}{lcr}
\hline \multicolumn{1}{c}{ Pernyataan } & \multicolumn{2}{c}{ Komponen } \\
\cline { 2 - 3 } & $\mathbf{1}$ & $\mathbf{2}$ \\
\hline $\begin{array}{l}\text { Kesesuaian antara hak dan kewajiban dalam } \\
\text { perjanjian kerja dengan prakteknya }\end{array}$ & 0,75 & 0,95 \\
$\begin{array}{l}\text { Kesesuaian HRD dalam menanggapi komplain yang } \\
\text { berkaitan dengan gaji }\end{array}$ & 0,749 & $-0,57$ \\
$\begin{array}{l}\text { Jumlah gaji yang didapatkan berdasarkan } \\
\text { perjanjian kerja }\end{array}$ & 0,532 & 0,173 \\
$\begin{array}{l}\text { Besaran gaji pada karyawan yang telah lama } \\
\text { bekerja dibandingkan yang baru bekerja }\end{array}$ & 0,532 & 0,583 \\
$\begin{array}{l}\text { Sarana dan Prasarana lingkungan kerja } \\
\text { Kemudahan komunikasi dengan } \\
\text { manajeman/atasan jika ada komplain yang } \\
\text { bekaitan dengan pekerjaan }\end{array}$ & 0,625 & $-0,391$ \\
$\begin{array}{l}\text { Tanggapan dan kepastian solusi dari } \\
\text { manajemen/atasan mengenai permasalahan yg } \\
\text { berkaitan dengan pekerjaan }\end{array}$ & 0,786 & $-0,421$ \\
$\begin{array}{l}\text { Jumlah cuti dan libur sesuai ketentuan yang } \\
\text { berlaku }\end{array}$ & 0,760 & $-0,389$ \\
$\begin{array}{l}\text { Kesesuaian informasi mengenai kebijakan waktu } \\
\text { kenaikan gaji dengan prakteknya }\end{array}$ & 0,522 & 0,215 \\
\hline & & 0,511 \\
\hline
\end{tabular}

Analisis faktor (Tabel 3) menunjukkan bahwa variabelvariabel yang membentuk kedua faktor (component) adalah variabel (pernyataan) 1, 4, 8, 9, 11, 12, 13, 22, dan 27. Untuk mengklasifikasikan variabel-variabel yang masuk kedalam faktor, maka dibandingkan nilai PCA antara kedua faktor. Nilai tertinggi menunjukkan bahwa variabel tersebut masuk kedalam faktor tersebut. Langkah selanjutnya adalah mengidentifikasi nama faktor-faktor tersebut sesuai variabel-variabel yang ada didalamnya (Tabel 4).
Tabel 4. Variabel yang membentuk faktor intrinsik dan ekstrinsik pada kepuasan kerja tenaga kesehatan di RSX

\begin{tabular}{|c|c|c|}
\hline Faktor & Pernyataan & $\begin{array}{l}\text { Klasifikasi Sub } \\
\text { Faktor }\end{array}$ \\
\hline Intrinsik & $\begin{array}{l}\text { Besaran gaji pada karyawan yang telah lama } \\
\text { bekerja dibandingkan yang baru bekerja }\end{array}$ & Penghargaan \\
\hline \multirow[t]{6}{*}{ Ekstrinsik } & $\begin{array}{l}\text { Kesesuaian antara hak dan kewajiban dalam } \\
\text { perjanjian kerja dengan prakteknya }\end{array}$ & Kebijakan RS \\
\hline & $\begin{array}{l}\text { Kesesuaian HRD dalam menanggapi masalah } \\
\text { yang berkaitan dengan gaji. }\end{array}$ & \\
\hline & $\begin{array}{l}\text { Jumlah cuti dan libur sesuai ketentuan yang } \\
\text { berlaku } \\
\text { Kesesuaian informasi mengenai kebijakan } \\
\text { waktu kenaikan gaji dengan prakteknya }\end{array}$ & \\
\hline & $\begin{array}{l}\text { Jumlah gaji yang didapatkan berdasarkan } \\
\text { perjanjian kerja }\end{array}$ & $\begin{array}{l}\text { Gaji dan } \\
\text { Kompensasi }\end{array}$ \\
\hline & Sarana dan prasarana lingkungan kerja & $\begin{array}{l}\text { Lingkungan } \\
\text { kerja }\end{array}$ \\
\hline & $\begin{array}{l}\text { Kemudahan komunikasi dengan } \\
\text { manajeman/atasan jika ada komplain yang } \\
\text { bekaitan dengan pekerjaan } \\
\text { Tanggapan dan kepastian solusi dari } \\
\text { manajemen/atasan mengenai permasalahan } \\
\text { yg berkaitan dengan pekerjaan }\end{array}$ & $\begin{array}{l}\text { Hubungan atara } \\
\text { atasan dengan } \\
\text { bawahan }\end{array}$ \\
\hline
\end{tabular}

Sumber: Data Statistik yang telah diolah, 2013

\section{DISKUSI}

\section{Karakteristik Responden}

Hasil penelitian menggambarkan bahwa responden sebagian besar termasuk dalam kelompok usia antara 2025 tahun (42\%) dan 26-30 tahun (44\%). Kedua kelompok usia ini termasuk dalam usia produktif. Status kepegawaian sebagian besar adalah pegawai tetap (64\%). Untuk menjadi pegawai tetap di RS $\mathrm{X}$, tenaga kesehatan harus minimal dikontrak dalam dua tahun, sehingga jumlah tenaga kesehatan yang bekerja diatas dua tahun lebih banyak dibandingkan yang bekerja selama 1-2 tahun (60\%). Seluruh responden telah bekerja di RS X lebih dari satu tahun sehingga seluruh responden memenuhi syarat inklusi penelitian

Berdasarkan teori Kachmar dan Velis dapat dihubungkan karakteristik responden dengan gambaran umum kepuasan kerja di RS X. Karakteristik yang dapat dihubungkan adalah umur responden serta lama bekerja. Dikatakan dalam teori tersebut bahwa terdapat hubungan antara usia karyawan dengan kepuasan kerjanya. Karyawan dengan usia yang lebih tua sampai dengan 60 tahun lebih cenderung tinggi kepuasan kerjanya. Hal yang sama berlaku pada lama bekerja, yaitu semakin lama karyawan bekerja maka semakin tinggi kepuasan kerjanya $(6,7)$. Dari karakteristik responden di RS X yang sebagian besar adalah usia dewasa muda dapat diasumsikan bahwa mereka cenderung sulit untuk dipuaskan oleh pekerjaannya. Sebagian besar responden lama bekerjanya lebih dari dua tahun yang seharusnya tingkat kepuasan kerjanya tinggi. Kedua asumsi tersebut perlu dibuktikan lebih lanjut dengan menggunakan analisis regresi untuk melihat pengaruh karekteristik responden di RS X terhadap tingkat kepuasan.

Gambaran Umum Kepuasan Kerja Tenaga Kesehatan di RS $X$

Secara umum tingkat kepuasan kerja tenaga kesehatan di 
RS X adalah cukup. Tingkat kepuasan ini dibentuk dari nilai mean faktor intrinsik dan ektrinsik yang sebagian besar berada pada kisaran nilai 2-4. Kepuasan kerja dipengaruhi oleh banyak faktor sehingga kepuasan kerja dapat mewakili sikap secara menyeluruh (kepuasan umum) maupun mengacu pada bagian pekerjaan tertentu. Artinya jika secara umum seseorang memiliki tingkat kepuasan sangat tinggi tetapi dapat juga merasa tidak puas dengan salah satu atau beberapa faktor yang mempengaruhi kepuasan kerja (8).

Terdapat dua faktor yang mempengaruhi kepuasan kerja menurut Herzberg dalam Luthans. Faktor pertama yaitu faktor motivator yang berhubungan dengan aspek-aspek yang terkandung dalam pekerjaan itu sendiri atau disebut juga faktor instristik (9). Pada penelitian ini yang termasuk sub faktor intrinsik adalah penghargaan, kesempatan berkembang serta tanggung jawab. Hal ini sesuai dengan teori Herzberg yang memasukkan prestasi, pengakuan, tanggung jawab dan pengembangan kesempatan untuk maju menjadi faktor intrinsik (9).

Faktor intrinsik merupakan faktor yang memotivasi seseorang untuk berprestasi yang bersumber dari diri individu tersebut sehingga dikenal sebagai faktor motivasional (10). Faktor ini merupakan sumber motivasi terkuat dalam diri karyawan karena dapat mendorongnya untuk memberikan seluruh kemampuannya dalam bekerja (9). Pada sub faktor penghargaan terdapat ketidakpuasan khususnya pada sistem reward. Hal ini dikarenakan belum adanya sistem reward baku yang diberlakukan di RSX. Penghargaan atau reward yang dapat diberikan kepada tenaga kesehatan berupa pernyataan atau pujian, surat penghargaan, hadiah, medali, kenaikan gaji dan sebagainya (10). Di RSX tenaga kesehatan mempersepsikan bahwa gaji tenaga kesehatan yang lama bekerja lebih besar daripada yang baru sebagai salah satu bentuk penghargaan dari Rumah Sakit. Seharusnya selisih antara gaji pegawai lama dan baru merupakan salah satu komponen dari remunerasi. Sistem penggajian RSX telah memakai sistem remunerasi dengan salah satu komponen yang menentukan besaran gaji adalah lama bekerja. Kesalahan persepsi ini dikarenakan kurangnya komunikasi antara manajemen dengan tenaga kesehatan mengenai pengertian dan perbedaan antara penghargaan dan sistem penggajian.

Sub faktor intrinsik yang kedua adalah kesempatan untuk berkembang. Variabel untuk sub faktor pada penelitian ini adalah kesempatan untuk jenjang karier dan mengikuti seminar atau pelatihan. Responden menjawab tidak puas untuk variabel kesempatan jenjang karier karena menurut persepsi mereka di RSX belum ada aturan baku yang mengatur mengenai jenjang karier. Tingkat kepuasan responden untuk variabel kesempatan yang sama dalam mengikuti seminar dan pelatihan adalah cukup. Jawaban mereka ini didasarkan pada fakta bahwa terdapat pendelegasian yang ditunjuk oleh atasan untuk beberapa seminar dan pelatihan tertentu, sehingga tidak semua tenaga kesehatan memiliki kesempatan yang sama. Pada subvariabel tanggung jawab tingkat kepuasan responden adalah cukup. Hasil ini dikarenakan pada situasi tertentu tenaga kesehatan masih merasa belum diberikan wewenang sepenuhnya untuk mengambil keputusan oleh atasan.

Faktor yang kedua adalah faktor ekstrinsik pada penelitian ini antara lain kebijakan RS, gaji dan kompensasi, teman sekerja, hubungan atasan dengan bawahan serta lingkungan kerja. Faktor ekstrinsik ini sesuai dengan teori Herzberg yang meliputi gaji, keamanan, hubungan kerja dengan atasan, teman sekerja dan lingkungan kerja (9). Subfaktor keamanan tidak dimasukkan kedalam variabel penelitian karena tidak valid.

Pada sub faktor kebijakan RS, hanya variabel waktu kenaikan gaji yang mendapat memberikan respon tidak puas oleh responden. Hal ini dikarenakan sebagian responden tidak tahu kapan memperoleh kenaikan gaji. Kebijakan kenaikan gaji di RS X sebenarnya telah ada dan disosialisasikan, namun ternyata sebagian besar tenaga kesehatan belum mengetahui kebijakan ini. Kemungkinan hal ini terjadi karena kurangnya komunikasi mengenai kebijakan yang sudah diterapkan antara manajemen dengan tenaga kesehatan. Pada sub faktor gaji dan kompensasi, tingkat kepuasannya adalah cukup. Variabel sub faktor ini adalah kesesuaian gaji dan kompensasi lemburan. Sebagian besar responden puas dengan gajinya karena sesuai dengan perjanjian kerja, namun ada beberapa yang menjawab tidak sesuai, begitu juga untuk kompensasilemburan.

Satu-satunya faktor ekstrinsik yang memiliki tingkat kepuasan tinggi adalah teman sekerja. Responden menilai puas terhadap teman sekerjanya karena mereka menganggap teman sekerjanya mudah diajak untuk bekerjasama. Pada sub faktor hubungan atasan dengan bawahan tingkat kepuasan responden adalah cukup pada semua variabel. Variabel tersebut adalah kemudahan komunikasi dengan manajemen atau atasan jika ada komplain yang berkaitan dengan pekerjaan dan tanggapan serta kepastian solusi dari atasan mengenai permasalahan yang berkaitan dengan pekerjaan. Pada variabel tersebut yang menjadi perhatian responden adalah kemudahan komunikasi yang dibangun oleh atasan. Mereka menganggap manajemen atau atasan belum memberikan kemudahan komunikasi dan tanggapan atas solusi masalah sesuai harapan.

Subfaktor ektrinsik yang terakhir adalah lingkungan kerja. Sarana dan prasarana merupakan variabel dari subfaktor ini. Tingkat kepuasan responden pada sarana dan prasarana adalah "cukup". Hal ini dikarenakan beberapa responden dari unit tertentu menjawab tidak puas pada sarana dan prasarana. Kelima faktor ektrinsik tersebut hanya memastikan bahwa karyawan tidak merasakan ketidakpuasan atau berada pada tiik nol landasan motivasi. Faktor instrinsik merupakan faktor pendorong dari dalam yang membuat karyawan puas terhadap pekerjaannya (9).

\section{Faktor Instrinsik dan Ekstrinsik yang Membentuk Kepuasan Kerja Tenaga Kesehatan di RSX}

Berdasarkan uji statistik dengan analisis faktor, terdapat satu variabel yang membentuk faktor intrinsik, yaitu reward (gaji) pada tenaga kesehatan yang telah lama bekerja dibandingkan dengan yang baru bekerja. Varibel ini termasuk dalam katagori penghargaan atau pengakuan. $\mathrm{Hal}$ ini berbeda dengan teori yang menyatakan bahwa variabel ini termasuk dalam faktor ektrinsik yaitu penggajian.

Faktor instristik yang memotivasi seseorang untuk berprestasi yang bersumber dari diri individu disebut juga sebagai faktor motivasional (10). Tenaga kesehatan akan termotivasi dengan penghargaan yang diperolehnya jika 
penghargaan tersebut dapat memuaskannya. Individu cenderung membandingkan penghargaan yang mereka peroleh dengan penghargaan yang diterima orang lain. Jika dianggap tidak adil, maka akan menimbulkan ketidakpuasan (11). Pada penelitian ini, tenaga kesehatan RS $X$ cenderung membandingkan gaji antara karyawan yang telah lama bekerja dengan yang baru bekerja sebagai bentuk penghargaan Rumah Sakit terhadap karyawannya. Menurut responden, RS $X$ masih belum memuaskan mereka dalam memberi penghargaan karena gaji antara karyawan lama beda sedikit dengan karyawan baru, bahkan ada beberapa unit yang gaji antara karyawan lama dan baru tidak berbeda. Untuk meningkatkan kepuasan mereka, RS X perlu membuat suatu kebijakan mengenai penggajian yang mengatur perbedaan besaran gaji antara karyawan lama dengan karyawan baru. Sistem penggajian harus memperhitungkan komponen lama kerja sebagai komponen terbesar dalam pengkalian gaji.

Faktor ekstrinsik mempunyai delapan variabel pembentuk. Delapan variabel tersebut dikategorikan menjadi empat sub faktor yang meliputi kebijakan RS, gaji, dan kompensasi, lingkungan kerja dan hubungan antara atasan dan bawahan. Pada sub faktor kebijakan RS terdapat empat variabel yang membentuk faktor ekstrinsik. Terdapat dua hal yang diperhatikan oleh tenaga kesehatan pada faktor ini, yang pertama adalah kesesuaian antara kebijakan RS yang tertulis dengan penerapannya. Hal yang kedua yaitu kesesuaian antara informasi yang didapat mengenai kebijakan RS dengan penerapannya. Tingkat kepuasan untuk kesesuaian antara kebijakan RS yang tertulis dengan penerapannya adalah "cukup". Hal ini dikarenakan masih terdapat penyimpangan antara kebijakan yang tertulis dengan penerapannya. Variabel untuk kesesuaian antara kebijakan yang tertulis dengan penerapannya adalah jumlah cuti dan libur. Pada IGD, Fisioterapi dan Rawat Inap B sebanyak $70 \%$ tidak puas dengan penerapan kebijakan tersebut. Responden merasa tidak puas kebijakan libur hari raya serta cuti yang tidak bisa diambil secara sepenuhnya.

Pada kesesuaian antara informasi mengenai kebijakan RS dan penerapannya, responden tidak puas pada variabel informasi mengenai waktu kenaikan gaji. Mereka beranggapan RS kurang komitmen dalam menerapkan waktu untuk kenaikan gaji sesuai informasi kebijakan yang mereka berikan. Selain itu juga terdapat jawaban responden yang mengatakan bahwa terdapat ketidakpastian informasi mengenai waktu kenaikan gaji. Permasalahan pada kebijakan RS yang menyebabkan tingkat kepuasan medium dan tidak puas adalah ketidaktepatan informasi yang diperoleh. Informasi didapatkan dari proses komunikasi. Komunikasi merupakan salah satu tolak ukur seberapa jauh kebijakan yang tertuang pada peraturan telah disampaikan secara jelas dan di intepretasikan sama serta dilakukan secara konsisten oleh infrastruktur yang melaksanakan kebijakan tersebut (12). Salah satu kesalahan penerimaan informasi disebabkan oleh komunikasi kebijakan yang tidak diberikan secara langsung, atau informasi kebijakan yang diberikan melalui orang ketiga. Salah satu cara untuk menanggulangi masalah ini, pemberian informasi mengenai kebijakan di RS $X$ harus dilakukan secara langsung oleh pembuat kebijakan. Cara lain adalah penguatan informasi dari pembuat kebijakan melalui memo yang mendukung informasi yang telah diberikan oleh perantara informasi (13).

Pada sub faktor gaji dan kompensasi, variabel yang membentuk faktor ekstrinsik adalah jumlah gaji yang didapatkan berdasarkan perjanjian kerja. Tingkat kepuasan pada variabel ini adalah cukup, artinya bahwa responden belum merasakan cukup dalam gaji yang diterima berdasarkan perjanjian kerja. Kepuasan gaji dan kompensasi merupakan faktor yang signifikan dan kompleks dalam mempengaruhi kepuasan kerja. Uang tidak hanya membantu memenuhi kebutuhan dasar mereka sesuai dengan teori Maslow, namun juga memberikan dasar untuk mencapai kepuasan kerja yang lebih tinggi (14). Perlu dilakukan pengkajian ulang mengenai besaran gaji yang ditawarkan dalam perjanjian kerja dan konsistensi di dalam pemenuhan besaran gaji sesuai dengan perjanjian kerja.

Sarana dan prasarana lingkungan kerja merupakan salah satu variabel pembentuk faktor ekstrinsik dari kepuasan kerja tenaga kesehatan di RSX. Sarana dan prasarana dapat menciptakan kondisi lingkungan yang baik. Dengan terciptanya kondisi lingkungan yang baik, prestasi yang tinggi dapat tercipta (10). Tingkat kepuasan responden pada variabel sarana dan prasarana adalah medium sehingga RS X harus melengkapi dan menyesuaikan sarana dan prasarana lingkungan kerja agar tingkat kepuasan kerja tenaga kesehatan meningkat. Dengan meningkatnya kepuasan kerja terhadap sarana dan prasarana diharapkan dapat menciptakan prestasi kerja yang baik.

Subfaktor hubungan atasan dan bawahan merupakan faktor terakhir pembentuk faktor ekstrinsik kepuasan kerja tenaga kesehatan di RS X. Terdapat dua variabel yang terlibat yaitu: kemudahan komunikasi atasan terhadap komplain yang berkaitan dengan pekerjaan dan tanggapan serta kepastian mengenai solusi atas permasalahan pekerjaan. Masuknya kedua variabel ini dalam pembentuk faktor ekstrinsik menggambarkan bahwa komunikasi merupakan hal yang penting di dalam hubungan antara atasan dengan bawahan. Arah komunikasi yang berpengaruh pada pembentukan faktor ekstrinsik ini adalah arah komunikasi dari bawah ke atas. Komunikasi dari bawah ke atas tersebut berupa komplain bawahan mengenai masalah yang berkaitan dengan pekerjaan serta permohonan untuk solusi atas permasalahan tersebut kepada atasan (13). Tingkat kepuasan pada komunikasi dalam hubungan antara atasan dan bawahan di RS $X$ adalah cukup. Menurut responden hal ini disebabkan adanya kesulitan dalam berkomunikasi dengan atasan. Kesulitan tersebut dikarenakan kurang tertampungnya komplain dari responden yang sebagian besar adalah pelaksana oleh kepala instalasinya, sehingga komplain kepada manajemen kurang terwakili. Penyebab yang kedua yaitu tanggapan solusi yang diberikan oleh atasan atau manajemen terhadap komplain mereka dianggap terlalu lama dan kurang pasti. Saran dari responden untuk melancarkan arus komunikasi dari bawah ke atas adalah dengan cara manajemen memberikan waktu khusus untuk berkomunikasi dengan pelaksana langsung. Teknisnya dapat dilakukan dengan membuat rapat antara manajemen dan karyawan atau manajemen menyempatkan diri turun ke lapangan untuk berkomunikasi.

Dari kedua faktor intrinsik dan ekstrinsik, faktor yang paling mempengaruhi kepuasan kerja adalah faktor intrinsik. Menurut teori Herzberg, faktor intrinsik adalah faktor motivasional yang mendorong karyawan untuk puas 
terhadap pekerjaannya. Pada faktor ektrinsik hanyalah faktor pemeliharaan yang memastikan karyawan tidak merasakan ketidakpuasan atau berada pada titik nol landasan motivasi. Dalam penelitian ini, faktor intrinsik yang berpengaruh adalah penghargaan RS terhadap tenaga berupa perbedaan gaji berdasarkan lama kerja. Untuk membuat tenaga kesehatan merasakan kepuasan kerja, maka pimpinan harus menyediakan faktor ini kepada tenaga kesehatannya. Penghargaan masa kerja tenaga kesehatan di RS $X$ telah tertuang dalam sistem penggajian remunerasi yang memperhitungkan masa kerjanya. Adanya tenaga kesehatan yang merasa penghargaan masa kerja dalam bentuk gaji yang kurang diperhatikan karena kurangnya informasi dari manajemen mengenai sistem remunerasi ini. Oleh karena itu, komunikasi merupakan hal yang harus diperhatikan agar tenaga kesehatan tidak salah persepsi tentang penghargaan terhadap dirinya.

Tingkat kepuasan kerja responden yang merupakan tenaga kesehatan di RS X secara umum adalah cukup puas. Faktor-faktor yang kemungkinan berpengaruh terhadap kepuasan tersebut adalah faktor intrinstik dan ekstrinsik. Faktor intrinstik yang terbentuk adalah penghargaan RS terhadap tenaga kesehatan berupa besaran gaji yang diberikan antara karyawan lama dengan karyawan baru. Faktor ekstrinsik yang terbentuk adalah dari kebijakan RS yang meliputi variabel: kesesuaian antara hak dan kewajiban dalam perjanjian kerja dengan prakteknya, kesesuaian manajemen SDM dalam menanggapi masalah

\section{DAFTAR PUSTAKA}

1. Niven PR. Balanced Scorecard Step by Step. Canada: John Wiley \& Sons, Inc; 2002.

2. Wang $\mathrm{L}$, Tao $\mathrm{H}$, Ellenbecker $\mathrm{CH}$, and Liu X. Job Satisfaction, Occupational Commitment and Intent To Stay Among Chinese Nurses: A Cross-Sectional Questionnaire Survei. Journal of Advanced Nursing. 2012;68(3): 539-549.

3. Yulida dan Harlyanti SW. Faktor-faktor yang Mempengaruhi Kepuasan Kerja Pegawai pada Pegawai Pengawas Dinas Luar Asuransi Jiwa Bersama Bumiputra 1912 Cabang Setiabudi Medan. Jurnal Manajemen Bisnis. 2009; 2: 25-32.

4. Solimun. Structural Equation Modeling dan Lisrel. Malang: Fakultas MIPA Universitas Brawijaya; 2005.

5. Huda S. Faktor-faktor yang Mempengaruhi Bidan Memilih Rumah Sakit Sebagai Tempat Rujukan Kasus Ibu Hamil Risiko Tinggi (Survei Pada Bidan PTT Desa Di Wilayah Pengembangan Kepanjen). [Tesis]. Universitas Brawijaya, Malang. 2011.

6. Akbar A. Pengaruh Karakteristik Pekerjaan, Karakteristik Organisasi dan Karakteristik Individu terhadap Kepuasan Kerja Karyawan Bank Swasta di Propinsi Sulawesi Selatan. Analisis. 2009; 6(2): 183192.

7. Mahesa D dan Indi D. Analisis Pengaruh Motivasi dan Kepuasan Kerja terhadap Kinerja Karyawan dengan Lama Kerja sebagai Variabel Moderating (Studi pada PT. Coca Cola Amatil Indonesia (Central Java). [Tesis]. Universitas Diponegoro, Semarang. 2010.

8. Baihaqi MF dan Suharnomo. Pengaruh Gaya yang berkaitan dengan gaji, jumlah cuti dan libur sesuai ketentuan yang beralaku dan kesesuaian informasi mengenai kebijakan waktu kenaikan gaji dengan prakteknya. Variabel yang membentuk faktor ekstrinsik pada gaji dan kompensasi adalah jumlah gaji yang didapatkan berdasarkan perjanjian kerja. Untuk variabel yang membentuk faktor ekstrinsik lingkungan kerja yaitu sarana dan prasarana lingkungan kerja. Variabel terakhir yang membentuk faktor ekstrinsik hubungan atasan dengan bawahan yaitu kemudahan komunikasi dengan atasan jika ada komplain yang berkaitan dengan pekerjaan serta tanggapan dan kepastian solusi dari atasan mengenai permasalahan yang berkaitan dengan pekerjaan. Terdapat masalah komunikasi antara tenaga kesehatan dan manajemen sehingga mempengaruhi persepsi terhadap kepuasan kerja.

Hasil penelitian menunjukkan bahwa terbentuk faktor intrinsik dan ektrinsik yang mempengaruhi kepuasan kerja. Faktor intrinsik yang terbentuk adalah penghargaan. Faktor ektrinsik yang terbentuk adalah kebijakan RS, gaji dan kompensasi, lingkungan kerja dan hubungan antara atasan dengan bawahan. Dari faktor-faktor intrinsik dan ekstrinsik yang membentuk kepuasan kerja diharapkan RS $X$ melakukan upaya di dalam meningkatkan kepuasan kerja berdasarkan faktor tersebut. Permasalahan mendasar yang timbul akibat dari ketidakpuasan pada faktor-faktor tersebut adalah komunikasi sehingga manajemen RS $X$ perlu melakukan komunikasi yang efektif kepada tenaga kesehatan di RS X.

Kepemimpinan terhadap Kepuasan Kerja dan Kinerja dengan Komitmen Organisasi sebagai Variabel Intervening (Studi Pada PT. Yudhistira Ghalia Indonesia Area Yogyakarta). [Tesis]. Universitas Diponegoro, Semarang. 2010.

9. Sahyuni R. Kepuasan Kinerja Karyawan, Analisis SWOT dan Rencana Strategik Pengembangan Sumber Daya Manusia dalam Upaya Meningkatkan Pelayanan di RUD H. Abdul Aziz Marabahan Kalimantan-Selatan Tahun 2009. [Tesis]. Universitas Diponegoro, Semarang. 2009.

10. Astrini R. Pengaruh Motivasi Instrinsik dan Motivasi Ekstrinsik terhadap Produktivitas Kerja Pegawai pada Kantor Pelayanan Kekayaan Negara dan Lelang Makasar. [Skripsi]. Universitas Hassanudin, Makasar. 2012.

11. Maria E. Hubungan Penghargaan Intrinsik terhadap Motivasi Kerja. Jurnal Bisnis dan Ekonomi. 2010; 17(1): 1-9.

12. Harsono D. Implementasi Kebijakan Sistem Informasi dan Manajemen Pertahanan Nasional (SIMTANAS) di Kantor Pertahanan Kabupaten Jepara. [Tesis]. Universitas Diponegoro, Semarang. 2009.

13. Novita RA. Analisis Peran Komunikasi Antara Pimpinan dan Karyawan dalam Menciptakan Lingkungan Kerja yang Efektif pada PT. Cakrawla Andalas Televisi. [Skripsi]. Institut Pertanian Bogor, Bogor. 2004.

14. Prabu A. Pengaruh Motivasi terhadap Kepuasan Kerja Pegawai Badan Koordinasi Keluarga Berencana Nasional Kabupaten Muara Enim. Jurnal Manajemen \& Bisnis Sriwijaya. 2005; 3(6): 1-24. 